\section{fateotcal Intelligence.}

\section{APPOINTMENTS.}

Wilbraham Falconer, M.D., has been elected Physician to the Bath United Hospital, in the room of Dr. Daniel, resigned.

John Torry Hester, Esq., bas been elected Surgeon to the Radcliffe Infirmary, Oxford, in the room of Mr. C. L. Parker, deceased.

\section{UNIVERSITY OF LONDON.}

Number and Average Age of Candidotes for Degrees in Medicine, and the Number that have passed the Etaminations in each year.

\begin{tabular}{|c|c|c|c|c|c|}
\hline \multirow{3}{*}{\multicolumn{2}{|c|}{ 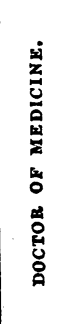 }} & 亗蓠离 & $\dot{\vec{c}}$ & 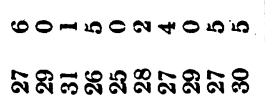 & N \\
\hline & & 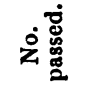 & & NーNッザシのニのニ & $\mathbb{N}_{\mathrm{i}}$ \\
\hline & & 它 & & 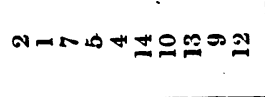 & $\approx$ \\
\hline \multirow{7}{*}{ 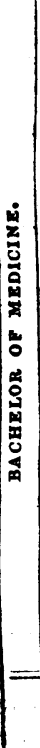 } & \multirow{3}{*}{ 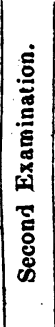 } & 苾 & $\mid \begin{array}{l}\dot{z} \\
\dot{\infty} \\
\dot{2}\end{array}$ & 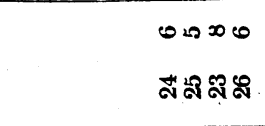 & 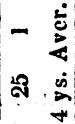 \\
\hline & & 总 & & 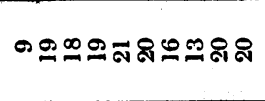 & $\stackrel{29}{=}$ \\
\hline & & 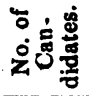 & & 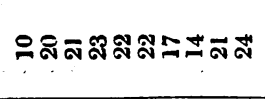 & $\stackrel{\Xi}{2}$ \\
\hline & \multirow{3}{*}{ 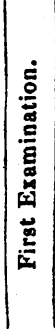 } & 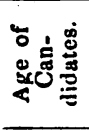 & $\mid \begin{array}{l}\dot{2} \\
\dot{2} \\
\dot{2}\end{array}$ & 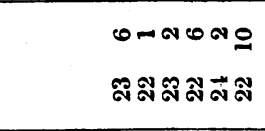 & 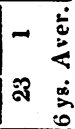 \\
\hline & & 完总 & & 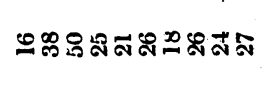 & $\vec{N}$ \\
\hline & & 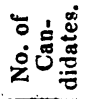 & & 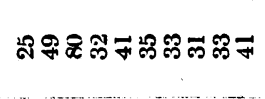 & \&్ \\
\hline & & & & 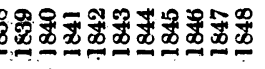 & \\
\hline
\end{tabular}

\section{QUEEN'S COLLEGE, BIRMINGHAM.}

Owing to unaroidable circumstances, the decision of the prizes for the last collegiale year was not given till a few days since. At a special meeting of the Council, the following gentlemen were announced as the successful candidates :-

Anatomy and Physiology:-(Medal)-Mr. Thomason, Shiffnal.

Practice of Physic:-(Medal)-Mr. Whittle, Leamington; (Hon. Certificate)-Mr. Moore, Hales Owen.

Surgery :-(Medal)-Mr. Whittle, Leamington.

Materia Medica:-(Medal)-Mr. Blake, Birmingham; (Hon. Certificate)-Mr. Low, Birmingham.

Chemistry :-(Medal)-Mr. Blake, Birmingham.
Midwifery:-(Medal)-Mr. Lane, Grosmont; (Hon. Certificate)-Mr. Stead, Congleton.

Forensic Medicine :-(Certificates)-Mr.Mills, Tipton ; Mr. Partridge, Darlaston.

Demonstrator's Prize :-Mr. Moore, Hales Owen.

Warneford Essay:- "On the Articulations of the Human Skeleton." Mr. Lane, Grosmont, (lst.); Mr. Dunn, Birmingham, (2nd.)

Governors' Gold Medals :-Mr. L3ne, Grosmont; Mr. Jones, Cleobury Mortimer.

\section{ROYAL COLLEGE OF PHYSICIANS. LECTURES.}

The Gulstonian Lectures will be delivered by $\mathrm{Dr}$. Gull, and commenced on the 16th inst.; the Croonian, by Dr. Conolly, on the 28th; the Lumleian, by Dr. Todd, March 9th ; and the lectures on Materia Medica, by Dr. G. Bird, March 2lst.

\section{SOCIETY OF APOTHECARIES.}

Gentlemen admitted Licentiates Thursday, February 1st. :-Oglethorpe Wakelin Barratt, Birmingham ; Francis Turner Welby King, Melton Mowbray ; Feiix Weekes Richardson, Banbury; William Thomas Garrett Woodforde.

\section{OBITUARY.}

Died, January 20th, at Canterbury, aged 92, Francis Dalley, M.D., formeriy of Stamford.

February 2nd, at Montrose, aged 42, David Burnes M.D., formerly of London.

February 3rd, at Hornchurch, Essex, Robert Wm Quennell, Esq., Surgeon.

February 4th, at Madeira, Nicholas George Hobson, Esq., Surgeon, late of London.

February 6th, at Ashburton, Devon, aged 52, John Soper, M.D.

\section{BOOKS RECEIVED.}

Essays on Infant Therapeutics, \&c., \&c. By John B Beck, M.D., Professor of Materia Medica and Medical Jurisprudence in the Callege of Phrsicians and Surgeons of the University of the State of New York, \&c., \&c. New York, U.S.: Dean. 1849. $12 \mathrm{mo}$ pp. 117.

On Infantile Laryngismus, \&c. By James Reid, M.D. Physician to the Generul Lying-in Hospital, and to the Infirmary of St. Giles and St. George, Bloomsbury, \&ce. London: Churchill. 1849. 8vo pp. 204.

The Borough of Hull, considered in Relation to the Health of its Inhabitants, \&c. By Henry Cooper, M.D. President of the Hull Literary and Philosophical Society Hull: Leng and Son. 1849. 8vo pp. 25.

Return of the Mortality in 117 Distriets of England, for the Quarter ending December 31st, 1848.

\section{ERRATA.}

Page 43, col. 1,' line 15 from the bottom, for "external" read internal; line 11 from the bottom, for "pressure" read presence.

TO CORRESPONDENTS.

Communications have been received from Dr. Copeman: Dr. Kingdon; Mr. Humphry; Mr. Humpage; Mr. Waldron; Mr. Spooner; Dr. Ballard; Profeceor Sands Cox; Mr. A. Prichard; Mr. T. L. Walford; Dr. Butler Lane; Mr. Nunneley ; Dr. Heaton, 